\title{
Factors Influencing Farmer Behavior Towards Training with Special Topics of Agribusiness in East Java, Indonesia
}

\author{
Joko Mariyono ${ }^{1, *}$ Tabrani Tabrani², Mahben Jalil'². Putu B. Daroini ${ }^{3}$, Evy Latifah ${ }^{3}$, \\ Apri Kuntariningsih ${ }^{4}$
}

\author{
${ }^{1}$ Agribusiness Study Program, Universitas Diponegoro, Semarang, Indonesia \\ ${ }^{2}$ Magister Management Program, Universitas Pancasakti Tegal, Indonesia \\ ${ }^{3}$ Assessment Institute for Agricultural Technology - East Java, Malang, Indonesia \\ ${ }^{4}$ Magister Management Program, STIEPARI Semarang, Semarang, Indonesia \\ ${ }^{*}$ Corresponding author. Email: jokomariyono@lecturer.undip.ac.id
}

\begin{abstract}
The training was implemented to equip farmers with knowledge and innovation targeted to chili and vegetable farming. Using survey data from East Java Province, this paper evaluates the impact of training implementation on the production of chili and tomato, knowledge of integrated crop management (ICM), and practices related to chili and tomato cultivations. This study utilizes a regression analysis to track the main factors affecting the impacts on the behavior and production, and average paired comparison of net income before and after FFS implementation. Results show robust indications across the two approaches. After participating in the program, this study finds that farmers have significantly more knowledge about ICM practices than before. This paper also finds suggestive evidence that improved knowledge about ICM practices can significantly improve tomato and chili productions. Eventually, this paper concludes that FFS can improve farming performance, and thus it is recommended that the approach can be applied to other crops across regions of Indonesia.
\end{abstract}

Keywords: Vegetables, Farmers' Capacity, Non-formal Education, Training

\section{INTRODUCTION}

Chili and tomato in Indonesia play a significant role in the country's economy, as both horticultural crops are source of income for many people, and source of food required to fulfill basic necessities along with rice as the primary source of calorie intake. Special for chili, any shock of production triggers the volatile price of foods, which can increase inflation. The vegetables benefit many people in rural and suburban areas by intensifying both economic production and employment [1].

Chili and tomato, along with other vegetables contribute to community health since the crops provide many vitamins and micronutrients. The availability chili and tomato in sufficient amount every day at affordable prices will support food and nutrition security at both national and community levels [2,3]. Eventually, this condition leads to achievement of sustainable development goals, particularly for the goals of zero hunger, good health and well-being and responsible consumption by consuming micronutrient-dense vegetables alleviates diseases linked to malnutrition.

The industry of chili and tomato should continually grow at a significant rate to balance the population growth rate that is still considered high. There is another challenge of agricultural land degradation and massive land conversion, however. This means that the productivity of the chili and tomato industry needs to grow faster than the population to fulfill the need. Agricultural technology suitable for both crops progressively develops because the government has established many horticultural research centers, private 
sectors, and international institutions. The centers have generated a mutual collaboration to enhance the productivity of chili and tomato.

The World Vegetable Center executed one of the collaborations, working together with the Indonesian Vegetable Research Institute, Assessment Institute of Agricultural Technology, and State and Private Universities in East Java. The collaboration formulated a package of integrated crop management (ICM) based on the development of integrated pest and disease management (IPDM). Such packages considered an improved knowledge and technology applicable to chili and tomato farming. Farmer field schools (FFS) have been selected as media to deliver the package of technology to about 1600 farmers who cultivate chili and tomato in East Java. This study evaluates the impact of FFS implementation on the performance of chili and tomato farming and farmer's capacity, indicated with the production of chili and tomato, knowledge of integrated crop management, and practices related to chili and tomato cultivations by using survey data from East Java Province.

\section{METHODOLOGY}

This study randomly selected 90 farmers who graduated from FFS in East Java. The selected farmers have been cultivating chili and tomato after completing the FFS. Theory of behavior was applied as the underlying analysis [4,5]. This analysis includes three aspects and procedures, explained as follows.

\subsection{Factors Influencing Farmer Behavior Toward Vegetable FFS Activities}

The analysis used to determine the factors that influence farmer behavior towards activities uses multiple linear regression analysis. The determining factors include the age of the farmer, level of education, arable land, the status of the land, activeness in farmer groups, frequency of participating in FFS activities, the role of extension officer, and production infrastructures. The model is formulated as follows.

$$
F B=\beta_{0}+\sum_{i=1}^{8} \beta_{i} X_{i}+\varepsilon
$$

where $F B$ is farmer behavior towards FFS activities, $\beta_{0}$ is a constant, $\beta_{i}$ is coefficients of impact, $X_{i}$ for $\mathrm{i}=1$, $2 \ldots, 8$ is factors affecting farmer behavior towards FFS activities, and $\varepsilon$ is error terms.

\subsection{The Influence of Farmer Behavior in FFS Activities on Vegetable Farming Production Level}

Analysis of farmer behavior in vegetable FFS activities with vegetable farming production levels uses multiple linear regression analysis where farmer behavior towards FFS activities consisting of farmer knowledge, farmer attitudes, and farmer skills towards increasing vegetable farming production.

\subsection{Support of Farmers for FFS Activities}

The response referred to in this study is the support of farmer behavior towards FFS activities, which is known from three assessment indicators, namely: farmer knowledge, farmer attitudes, and farmer skills in participating in FFS activities. The three behavioral indicators can be done by calculating the total score in the list of questions asked to the respondent. The scoring method is carried out using a Likert scale, and then a proportion test is carried out regarding the level of farmer response. Further analysis is to analyze the impact farmers behavior on value of production, as follows.

$$
V P=\alpha_{0}+\sum_{i=1}^{3} \alpha_{i} Z_{i}+\varepsilon
$$

where $V P$ is value product of chili and tomato, $\alpha_{i}$ is coefficients of impact, $Z_{i}$ is farmer knowledge, farmer attitudes, and farmer skills that affect farmer behavior towards FFS activities.

Overall behavioral support from the aspects of farmer knowledge, farmer attitudes, and farmer skills in participating in the FFS activities can be divided into three categories: low behavior support, moderate behavior support, and high behavior support.

\subsection{Net-income before and after FFS}

The impact of FFS on net revenue was assessed by comparing the level before and after FFS using paired ttest. This model is considered robust because it eliminates factors embedded in farmers. When the factors were differenced, they are canceled out, and the remaining difference is the attributable impact.

\subsection{Testing for hypotheses and diagnostic tests}

Testing the significance of the parameters was carried out in two stages: simultaneously to see the effect of all factors of farmer behavior on increasing vegetable production using the F-test and individually to see the significance of each factor using a t-test. The hypotheses are formulated as follows.

$$
\mathrm{H}_{0}: \beta_{i}=\alpha_{i}=0
$$

$\mathrm{H}_{1}$ : The $\mathrm{H}_{0}$ is false.

Several diagnostic tests were conducted to fulfil classical assumptions in the multiple regression analysis to get the best linear unbiased estimators, leading to correct conclusions [6]. 


\section{RESULTS AND DISCUSSION}

Table 1 shows the estimated factors determining farmers' behavior in FFS activities. There is an influence of farmer's age on farmer's behavior on Vegetable FFS activities, meaning that the younger the farmer's age means that changes in farmer's behavior towards FFS activities will be better. Young farmers generally have better conceptual aspects than older farmers regarding knowledge, attitudes, and skills. At a young age, the nature of being curious and wanting to try something new is enormous. The hypothesis states that the younger the farmers are, the better the changes in farmer behavior towards FFS activities have been proven.

There is a significant influence of the level of farmer education on farmer behavior in FFS activities. This means that farmers who have a higher level of education will undoubtedly be able to accept and understand the guides' explanations easily; therefore, farmers who have a higher level of formal education will be better in terms of understanding, attitudes, and tendencies to act. In addition, in each existing forum, farmers who have higher education will usually be more active in asking questions, issuing opinions, and seeking information about FFS.

There was no significant effect of land area on farmer behavior in FFS activities. The hypothesis that the farmers' broader cultivated land increased the farmer's behavior towards FFS activities was rejected. This is because this FFS activity does not differentiate the area of cultivated land owned by farmers. Farmers who have narrow arable land will have the same opportunity as farmers with relatively large cultivated land to participate in the FFS activity. The level of change in farmers' behavior towards the FFS activities subject to each farmer personally and is not influenced by the area of land ownership cultivated by farmers for their farming activities.

Table 1. Determining factors of farmers' behavior

\begin{tabular}{lcc}
\multicolumn{1}{c}{ Independent } & Coefficient & Sig. \\
Constanta & -3.954 & \\
Farmer age & 0.024 & 0.041 \\
Farmer education & 0.172 & 0.026 \\
Land area & 0.120 & 0.038 \\
Land status & -0.014 & 0.966 \\
Activeness of farmer group & -0.016 & 0.486 \\
Frequency of meeting & 0.078 & 0.091 \\
Role of extensionist & 0.029 & 0.043 \\
Infrastructure & 0.028 & 0.091 \\
\hline Source: Primary Data & &
\end{tabular}

Source: Primary Data, 2019

There is no significant effect of land status on farmer behavior in FFS activities. If the land is owned, it does not mean that farmers' behavior towards FFS activities will be better than farmers who rent land. The same objective between owner farmers and tenant farmers in farming activities is why this factor does not significantly affect farmer behavior. Basically, owner farmers and tenant farmers and tenant farmers have the same goal in managing a vegetable farming business, namely in the form of income earned to meet the needs of daily life, meaning farming in this sense is a job. Farming as a job gives the same characteristics between owner farmers, tenant farmers, and sharecroppers. Both owner farmers, tenant farmers, and tenant farmers who want to be serious about this work will positively respond to a better behavior change towards FFS activities. However, farmers who are less serious about their work will undoubtedly respond to bad behavior.

There is no significant effect of activeness in farmer groups on farmer behavior in FFS activities. This indicates equal treatment and opportunity for farmer group members to participate in FFS activities, not differentiating between active farmer group members, passive farmer group members, and even farmer group managers. All members of the farmer group receive the same treatment and opportunity to participate in FFS activity. The behavior change that is expected to occur still depends on each farmer participating in the FFS. Although in the initial hypothesis, it is expected that the more active members in the farmer group, the easier it will be to accept new technological innovations in this FFS activity, and the behavior will change for the better. However, in this case, it did not happen.

There is a significant effect of the frequency of participating in FFS activities on farmer behavior. The more often farmers participating in the FFS attend the vegetable FFS activity meetings, the better their farming activities in their farming activities. This obviously will be preceded by a change in knowledge, a change in attitude, and a change in skills after attending the FFS activity meeting.

There is a significant effect of the role of extension agents on farmer behavior in FFS activities. This shows that the role of extension workers as assistants to farmers in farming who have duties as a motivator, dynamist, and disseminators can change the behavior of farmers to do better farming. The better the role of the extension worker, the better the farmer's behavior changes. With good and intensive extension assistance, it will facilitate and enlarge the behavioral changes of the FFS participants.

There is a significant effect of the availability of production facilities and infrastructure on farmer behavior in FFS activities. This shows that the availability of facilities and infrastructure owned or available at the village level, farmer groups, and farmers can increase farmer behavior changes. The more complete the facilities and infrastructure owned, the higher the level of change in farmer behavior. Completeness of facilities and infrastructure is more supportive of farmer behavior in farming than the previous farming method. The availability of complete 
facilities and infrastructure will undoubtedly facilitate and facilitate this FFS activity.

Table 2 shows estimated influences of farmers' behavior on the performance of farming, indicated with production. Based on the multiple linear regression analysis above, among the three components of farmer behavior, only farmers' knowledge positively affects increasing vegetable farming. Knowledge can increase production because it is related to technology. If farmers' knowledge increases, farmers are more responsive to the adoption of new technology.

Table 2. Effect of farmer behavior on production

\begin{tabular}{lcc}
\multicolumn{1}{c}{ Independent } & Coefficient & Sig. \\
\hline Constanta & -23.967 & \\
Farmers' knowledge & 0.592 & 0.036 \\
Farmers' attitude & 0.192 & 0.506 \\
Farmers' skill & 0.014 & 0.964 \\
\hline Source: Primary Data, 2019 & &
\end{tabular}

Two of the components of farmer behavior, namely farmer attitudes and farmer skills, have no significant effect on increasing vegetable production. In this case, the change in the attitude of the farmers did not affect the vegetable farming activities. It can be said that the change in the attitude of the farmers after joining FFS is neutral, not destructive or constructive [7]. Changes in skills after attending school do not affect production. It can happen because many other factors affect production. This can be seen from the very small $\mathrm{R}^{2}$ value, which indicates that there are still many factors excluded in the analysis model. One of the reasons is that the farmers' skills are good for vegetable production. These skills have been obtained from experience during vegetable farming. This will be different if farmers are farming with new plants.

Table 3. Support of farmers to FFS

\begin{tabular}{lcrr}
\multicolumn{1}{c}{ Support } & Score & Number & \multicolumn{1}{c}{$(\%)$} \\
\hline Low & $0-91$ & 0 & 0 \\
Moderate & $92-181$ & 28 & 31,11 \\
High & $92-181$ & 62 & 68,88 \\
\hline Total & & 90 & 100,00 \\
\hline
\end{tabular}

Source: Primary Data, 2019

Table 3 shows that farmers who have low behavioral support are $0 \%$. Farmers who have moderate behavior support are $31 \%$, and farmers with high behavioral support are $69 \%$. This shows that most farmers have a high level of behavioral support for the FFS activities. This result follows the first hypothesis in this study, assuming that more than $50 \%$ of farmers have high behavioral support for FFS activities. More than $50 \%$ of farmers have high behavioral support for the FFS activities. The hypothesis stating that more than $50 \%$ of FFS farmers have high behavioral support for FFS activities has been proven. The high level of support for farmer behavior can be seen from the large score of farmer behavior consisting of knowledge, attitudes, and skills, obtaining a score of $70.82 \%$ of the maximum score in the high category. This shows that the farmers support and participate well in this FFS activity.

Table 4 shows the difference in profit level between before and after FFS participation. The net revenue level before and after FFS participation is significantly different. This is the main resultant of FFS perceived by farmers. Farmers' motivation to participate in FFS until finished is for the production motive while keeping the efficient use of inputs; or keeping the production unchanged while the use of inputs declined. The production of chili and tomato increased significantly as the knowledge changed after participating in FFS. This expectedly occurred because, in the FFS, farmers learned a technological package. The package has been previously verified by researchers in the field before disseminated to the farmers [8]. Technology components include seed technology, fertilizers, fertilizer application, soil fertility, soil management, biological control, integrated pest and disease management, and efficient water irrigation [9,10]. Farmers at least adopted two components of the technology. The selection of technology adopted by each farmer is subject to the problem facing them in their farming system.

Table 4. Mean comparison of net revenue (mil.

IDR/0.1ha)

\begin{tabular}{lcc}
\hline Net-revenue (mil IDR/0.1 ha) & Std. Dev. \\
\hline After FFS & 24.422 & 22.7492 \\
Before FFS & 21.578 & 21.1798 \\
Difference & 2.844 & 8.7048 \\
\hline t-test & 3.100 & $\mathrm{p}>\mathrm{t}=0.003$ \\
\hline Source: Primary Data, 2019 &
\end{tabular}

\section{CONCLUSION AND RECOMMENDATION}

Vegetable production needs to increase continually in a sustainable manner to keep pace with population growth. Vegetables, including chili and tomato, provide a significant contribution to economic development progress and sustainable development goals since such commodities have high-value and nutritional content. A technological package has been formulated and disseminated to farmers through FFS in order to achieve the objective. Farmers in East Java who have received and adopted the technological package perceived that they enjoyed the benefits of human capital, physical capital, and financial capital. The knowledge of farmers was enhanced, and this impacted the production of vegetables. The resultant was the increase in net income after the completion of FFS. In one case, there might be constant production before and after FFS, but the input use significantly dropped. In another case, the production might increase with the same level of input costs. The outcome beyond this study is that FFS has effectively delivered a technological package. The outcome is not only the improvement of farming performance but also the empowerment of farmers. It is strongly recommended 
that FFS is applied to disseminate other technological packages for vegetable production in particular and other agricultural commodities in general.

\section{AUTHORS' CONTRIBUTIONS}

Joko Mariyono contributed to the paper in terms of preparing manuscript, data analysis and interpretation, final check and submission. Tabrani Tabrani, Mahben Jalil, Putu B. Daroini, Evy Latifah and Apri Kuntariningsih contributed to this paper in terms of discussions on agronomic, socio-economic and technical aspects as well as policy formulation.

\section{ACKNOWLEDGMENTS}

The authors thank the enumerators who compiled the data during the survey. Farmers who have provided time and information related to farming practices during the survey were appreciated. This is also to acknowledged that the study is part of "Vegetables for Indonesia" project funded by USAID through The World Vegetable Center. The authors are responsible for interpretations and any shortcomings of the paper.

\section{REFERENCES}

[1] K. Weinberger, and T. A. Lumpkin, 2007. Diversification into horticulture and poverty reduction: A research agenda. World Development, 35(8), pp: 1464-1480.

[2] A.F., Wijaya, A., Kuntariningsih, S. Sarwono, and A. Suryono, 2021a. Malnutrition mitigation and community empowerment through the sustainable food reserve programme in Indonesia, Development in Practice, 31(1) pp: 37-48.

[3] A.F., Wijaya, A., Kuntariningsih, S. Sarwono, and A. Suryono, 2021b. Role and contribution of vegetables in mitigating malnutrition through a sustainable food reserve program, International Journal of Vegetable Science, 27(1), pp: 65-75.

[4] S. Robbins, and T. Judge, 2013. Organizational Behavior Fifteenth Edition. New Jersey: Pearson Education, Inc.

[5] S.P. Robbins, 1998. Organizational Behavior: Concepts, Controversies, Applications (8th Edition) 8th Edition, Prentice Hall

[6] M. Verbeek, 2003, A Guide to Modern Econometrics, John Wiley and Sons, Chichester.

[7] D. Broniatowski, and M. Avnet, 2015. Expert teams and shared knowledge networks: review and future directions. IIE Annual Conference. Proceedings, Institute of Industrial and Systems Engineers (IISE), Jan. 2015, p: 1419.
[8] J. Mariyono, 2020. Improvement of economic and sustainability performance of agribusiness management using ecological technologies in Indonesia. International Journal of Productivity and Performance Management. 69(5), pp: 989-1008.

[9] G.C., Luther, J., Mariyono, R.M Purnagunawan,., B. Satriatna, and M. Siyaranamual, 2018. Impacts of farmer field schools on productivity of vegetable farming in Indonesia, Natural Resources Forum, 42 (2), pp: 71-82.

[10] J. Mariyono, 2019, Farmer training to simultaneously increase productivity of soybean and rice in Indonesia. International Journal of Productivity and Performance Management, 68(6), pp: 1120-1140. 